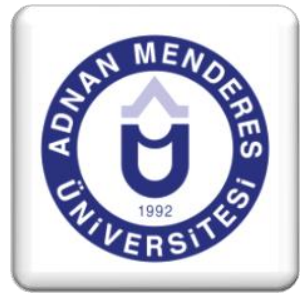

\title{
Örgüt Çalışanlarının Sahip Olduğu Yeteneklerin Kalitesi ve Derinliği
}

Tamer KEÇECIOĞLU ${ }^{1}$, Mustafa Kemal YILMAZ ${ }^{2}$, Hakan ERKAL, Sevgi Basar POSTA

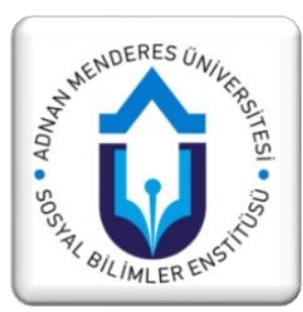

\section{ÖZET}

Günümüz küreselleşen dünyasında rekabet artmış, artan rekabet sayesinde insan faktörü ön plana çımaya başlamıştır. İşletmeler yaşanan bu değişim sürecinde çalışanlarına önem vererek rekabetçi avantaj sağlayacaktır. $\mathrm{Bu}$ nedenle İşletmede çalışan bireylerin yeteneklerinin ortaya çıkarılması ve bu bireylerin elde tutulması günümüzde önemli hale gelmiştir. İşletmeler için çalışanların seçilmesi, eğitilmesi ve örgüte bağl1lıklarının sağlanmasında en etkili ve çağdaş yönetim anlayışlarından birisi de yetenek yönetimidir. Bu çalışmada stratejik yetenek yönetimi ve yüksek potansiyelli çalışan kavramları incelenecek ve yapılan araştırmayla önemi irdelenecektir. $\mathrm{Bu}$ çalışmanın amacı işletmelerin sahip oldukları yeteneklerin farkında olup olmadığını belirlerken, eğer farkında ise kalitesi ve derinliğinin ne ölçüde olduğu, bu doğrultuda işletmelerde yetenekler konusunda yapılan uygulamalar neler olduğunu, yüksek potansiyelli çalıșana bakış açılarının neler olduğu ve son olarak da yetenek yönetimi programlarının olup olmadığını belirlemektir. Çalışmada kurumun hedef ve stratejilerinin belirlenmesi, kilit pozisyonların belirlenmesi, yetenek havuzu oluşturulması, eğitim ve geliştirme, performans değerlendirme, elde tutma ve bağlılık ve kariyer geliştirme gibi yetenek yönetimi süreçlerini oluşturan kavramlarla ilgili 18 özel şirket ve 4 kamu kurumu, örgütlenmesi yaygın, köklü tarihsel geçmişi olan, geniş kitlelere hizmet veren ve kısmen personel sayısı fazla 22 işletmenin insan kaynakları yöneticiler/çalışanlarına ile özel grup çalışması yapılmıştır. Gelen katılımcılara aynı zamanda 4 soruluk sıralama soruları olan bir anket uygulanmıştır. Odak grup çalışması ve uygulatılan bir anketle önemleri ve bu kavramların işletmeler açısından yararları belirlenmeye çalışılmıştır. Araştırma sonucunda yetenek yönetimi programlarının işletmelerin yarısında olduğu, yeteneklerin ayırt edici özellikleri olduğu, programın en çok yedekleme için kullanıldığı ve motive edici etkisi olduğu belirlenmiştir. Bu doğrultuda, en önemli kavramın yeteneklerin elde tutulması kavramı olduğu ve bunlar için çeşitli yöntemler uygulanması gerektiği belirtilmiştir.

Anahtar Kelimeler: Yetenek, Yetenek Yönetimi, Stratejik Yetenek Yönetimi, Yüksek Potansiyelli Çalı̧anlar

\footnotetext{
${ }^{1}$ Yrd. Doç. Dr. İktisadi ve İdari Bilimler Fakültesi İşletme Bölümü Yönetim ve Organizasyon Ana Bilim Dalı

${ }^{2}$ Doç. Dr. İktisadi ve İdari Bilimler Fakültesi / İşletme
} 


\title{
The Quality and Depth of The Talents of The Organization's Employees
}

\begin{abstract}
In today's globalizing world, the competition increased cause of that human factor has come to the forefront. During this change, businesses pay more attention to their employees to get an competitive advantage. Thanks to this result, nowadays discovering the abilities of individuals and retention of them are too important in businesses. Talent management is one of the most effective and contemporary management approaches to the selection, training and coordination of employees for businesses. In this study, the importance of talent management and the concept of high potential employees will be research. Also, the aim of this research is that whether the businesses are aware of their abilities or not. If businesses are aware about that this research tries to get what is the quality of these talents, what are the businesses' applications and programs about talent management and what are the firms' point of views about high-potential employees. Also, for this study, a special group work was done with human resources managers or employees who work in 18 private and 4 public companies which are really well known and have so many workers to define the objectives, the strategies, key positions of the firms and get the information about the firms' concepts about talent management periods, performance evaulation stages, devolopment of career management, retention and loyalty. Also, a questionnaire which has 4 questions was applied to these participants. Thanks to focus group work and the survey, the importance of above concepts was tried to be revealed. After the applied surveys, it was revealed that the half of the firms have specific talents and talent management programs which motivate them and are useful during backup periods. Also, it is stated that the most important concept is having an ability to hold the talents because of that various applications or techniques should be applied by firms to keep this specialty.
\end{abstract}

Keywords: Talent, Talent Management, Strategic Talent Management, High Potential Employees 


\section{Giriş}

Örgütlerin sahip olduğu yeteneklerin kalitesi ve derinliği en son aşamada "örgütün başarısını" belirler. Başarıdan kasıt sürdürülebilir rekabetçi avantaj kazanılması ve devam ettirilmesidir. Yeteneklerin yönetilmesi rekabetçi avantajın temelini oluşturan örgütsel yapının içerisinde yer alır. Bu noktada insan kaynakları yönetimi yapabilirliklerin oluşturulmasında mimar ve katalizör görevlerini üstlenir. Bu görevin içerisindeki en önemli konu, örgütün yetenek yönetimini bir "kültür" olarak algılaması ve bir yol gösterici eşliğinde iş stratejileri ile yetenek stratejilerini hedeflere ulaşmak için aynı düzlemde birlikte yürütmesidir.

Yetenek yönetimi süreçleri, yetenek yönetiminin örgüt içerisinde oluşturulması ve yayılmasını sağlayan süreçlerdir. $\mathrm{Bu}$ sürecin içerisinde yeteneklerin cezp edilmesi, yetkinliklerine göre değerlendirilmesi ve bunun sonucunda seçilmesi, eylem planlarının geliştirilmesi ve gözden geçirilmesi, geliştirilmesi ve son olarak örgüte bağlılıklarını sağlayarak elde tutulmasını sayılabilir. Bu süreçlerin başarısı için süreçlerin birbirleri ile ve insan kaynakları süreçleri ile bütünleşik ve bağlı olarak çalışması gereklidir. Bu aşamada insan kaynakları yöneticisinin en önemli sorumluluğu, örgütün kısa ve uzun vadeli hedef ve stratejilerini dikkatte alarak yine bununla bağlantılı olarak kısa ve uzun vadeli yetenek akışının farkına varacak bir mekanizma kurmak ve işletmektir. Gubman ve Green (2007) yetenek yönetimini insan kaynakları programları ve süreçlerinden ayrı bir konuma yerleştirirken programlanmış yaklaşımları içermesi gerektiğini savunmaktadırlar. Boudreau ve Ramstad (2007) insan kaynaklarının örgütlerde yeteneklerin yönetilmesinde kanıtlara dayalı karar vermeyi temel alması gerektiğini ifade ederlerken yetenek yönetimini insan kaynaklarının evrimleşmesindeki son aşama olarak ifade etmişlerdir. Bunun yanında yetenek kavramını belirli kişiyi hedef alan, bireylerin yetkinliklerini doğrultusundaki örgütteki yerini ifade edem bir kavram olarak ele almaktadırlar. Eğer bir grubu temsil ediyor ise "havuz" ismiyle ele almaktadırlar. Bunun yanında hızlandırıcı havuzlar (Byham, Smith ve Paese, 2002) ve temel yetenek havuzları (Boudreau ve Ramstad, 2005) isimlerini de almaktadır. Havuzlar yeteneğe "dışlayıcı" bakış açısını temsil eden bir eğriltileme olup farklılaştırıcı yatırımlara da olanak tanır. Örgütlerdeki yapı ve mekanizmalardaki yalınlaşma, yeteneğin doğasındaki kıtlık ve taklit edilememezlik, rekabetçi dinamiklerdeki kaotik değişimler stratejik katkıda yeteneğe odaklanılan "dar ve yoğunlaşık" bir bakış açısını da gündeme taşımışlardır.

Huselid ve Becker (2011) insan kaynakları yönetiminin örgütler açısından kitli bir rol oynadığını, temel olarak stratejiyi farklılaştırabilen bir insan kaynakları mimarisinin geliştirilmesinin çoğu örgüt açısından değer yaratmanın önemli bir kaynağ 1 olduğunu ifade etmiştir. Örgütlerein insan kaynakları açısından stratejik öncelik olarak etkin yetenek yönetimi stratejileri oluşturması gerektiği belirtilmiştir (Carden ve Mendonca, 2005). Bu öncelik SHRM ve PwC'nin çalışmalarında da kendini hissettirmektedir. Guthridge, Komm ve lawson (2006) nun yaptığı çalışmada yetenek yönetimi programlarının başarısını etkileyen faktörler olarak; kıdemli yöneticilerin yetenek yönetimine etkin ölçüde bağlılık hissetmemeleri, örgüt yapılarındaki engeller ve yöneticilerin performans açısından insanları farklılaştırıcı düşüncede olmamaları sayılabilir. Cohn, Khurana ve Reeves (2005) güçlü bir şekilde yaratılan etkin yedekleme planlaması ve liderlik geliştirme programları üzerinde durmuşlardır. Doğru rolde doğru yeteneklere sahip olmanın örgütlerin başarısında önemli olduğunu belirtmişler. Diğer bir önemli konunun yetenek yönetimi programlarının etkin liderlerin geliştirilmesi konusuna öncelik vermesi gerekliliği olduğunu ifade etmişlerdir. 
Bunun yanında örgütlerin yedekleme planlama ile yönetici eğitim ve geliştirme programlarını bütünleştiren örgütlerin genellikle başarılı ve takdir edilenler olduğunu savunmuşlardır. Bu felsefeyeye Michaels ve arkadaşları (2001:19-22) tarafından yetenek zekası ismi verilmiştir. Örgütlerin tüm seviyelerinde en iyi yeteneklere sahip olmak, yöneticilerin istedikleri bir durumdur. Bu doğrultuda, yöneticilerin yetenek havuzlarını kuvvetlendirmelerinin temel görevleri olduğu, örgüt performansına yeteneklerin öncülük edeceği anlayışı benimsemeleri gerektiği ve yeteneklerin örgütün işleyişi konusunda en değerli parça olduğu konularına önem vermeleri ve buna göre stratejiler oluşturmaları gerekmektedir.

\section{Stratejik Yetenek Yönetimi}

Cauley ve Wakefield (2006) yetenek zekası kavramını ortaya koymuştur. Yetenek zekasını, uzun vadede bağlılık gerektiren kavramları görme biçimi ve tutumu olarak tanımlamışlardır. Liderlik geliştirmeyi öncelikli bir konu haline getirme, bağlılık için zorunlu zaman harcanması da bu konu içerisinde ele alınmaktadır. Yetenek yönetimine sahiplenme ve sürece dahil olunması bir yetenek zekasıdır. Yetenek her yöneticinin ve liderin devredilmeyen asli görevi olduğu anlayışının bir kültür gibi kökleşmesi ve bir yaşam biçimi haline gelmesi gerekir. Olmazsa ne olacağını PwC (2012), kronik yetenek açığı olarak belirlerken CEO ların \%53 ünün en önemli zorluğu kilit yeteneklerin kaybı olduğunu, bunların olasıl kayıplarının gerçek maliyetinin 6-24 aylık maaşlarına denk geldiğini, artan ölçüde küresel ekonomilerin 1sınması ve toparlanması ile örgütlerden ayrılmayı isteyenlerin özellikle kilit pozisyondakilerin artacağını öngörmektedir. Bu öngörümün temelinde örgütlerin yetenek yönetimi kavramını temel bir iş önceliği olarak ele alması yatmaktadır. Şu an ki ve gelecekteki iş ihtiyaçları ve stratejik hedeflere ulaşmak adına yetenekleri bulmak, çekmek, geliştirmek ve elde tutmak için örgütlerde tasarlanan ve hayata geçirilen süreçler ve kültürel normlar bütününün bütünleştirilmesi biçiminde yapılacak bir tanımlamanın esas kaygısını mevcut ve gelecekteki işler ve ayakta kalabilme/nefes alabilme oluşturmaktadır. İş stratejileri tarafından yönlendirilen diğer insan kaynakları süreçleri ile bütünleştirilmesi, temel bir iş uygulaması olarak görülmesini daha öncede ifade etmiştik. Özellikle yetenek yönetiminin stratejik bir rol üstlenmesinin görülmesi, genelde insan kaynaklarında olduğu gibi yetenek yönetiminin de bir "eksen kayması" ile stratejik forma bürünmesi gerekir.

Collings ve Mellahi (2009) bu nokta da stratejik yetenek yönetimine çok geniş bir tanım getirmiştir; örgütlerde sürekli bağlılığı garanti etmede ve yetkin çalışanlarla bu pozisyonları doldurmasını kolaylaştırmada farklılaştırılan insan kaynakları mimarisinin geliştirilmesi ve bu rollerin doldurulmasında yüksek performans ve potansiyel havuzlarının geliştirilmesi ve örgütlerin sürdürülebilir rekabetçi avantajına farklılaştırma katkısı sağlayan kilit pozisyonları sistemlerinin tanımlanmasının dahil olduğu faaliyetler ve süreçlerdir. Yetenek kavramına getirilen bu "stratejik" bakış açısı özellikle "yetenek savaşları" mottosu ile ortaya çıkan kavram yeteneğe "geniş" bakış açısı getiren geleneksel kavramdan daha dar/elit paradigmal dönüşümü gündeme getirmektedir. Özellikle bu konudaki literatüre katkıda bulunanlar (Hambrick ve Mason, 1984; Miller, Burke ve Glick, 1998), yanında stratejik insan kaynakları açısından bakanlarda (Huselid, Jackson ve Schuler, 1997; Schuler, 1989; Wright ve McMahan, 1992) mevcuttur. Bu paradigmal dönüşüme katkıda bulunma anlamında katma değer yaratan ve yerine bulunması zor teknik yetkinlikler başlangıçta bir stratejik varlık olarak görülürken, Zuboff (1989) stratejik yeteneğin iş stratejilerinde önemli olduğunu, Stewart (1997) ise stratejik yeteneğin örgütlerdeki tüm seviyelerde bulunması gerektiğini savunmaktadır. Lawler (2008:2) örgütlerin bürokratik yapı ve güç ağırlıklı olması, bir 
maliyet kalemi olarak bakılması nedeni ile rekabetçi avantajın birincil kaynağı olmadığı görüşü ile yukarıda ifade edilen savlar örtüşmektedir. Örgüt içi liderlik geliştirme, yedekleme yönetimi ve havuzlama sistemleri örgütlerin performansının ve uzun vadeli ayakta kalabilmelerinin en önemli belirleyicisidir.

Schuler (2015) yetenekleri yönetmede 5-C isimli bir model çerçevesi geliştirirken şirket değeri, marka ve kültürle ilişkisi kurulurken yeteneklerin en üst \%3 lük bir gruba ait olduğunu, bu grubun şirketin başarısı ve stratejileri içerisinde yer almayı, stratejiye büyük katkıda bulunmayı, doğru firsatlar yoluyla şirket içerisinde gelişmesini istedikleri, esnek ve uyarlanabilir olmaları nedeni ile örgütün başarısı ve stratejilerini sürekli olarak geliştirmeyi alışkanlık haline getirdikleri ve kendilerini şirketin kısa ve uzun vadeli başarısı için ihtiyaç duyulduğunu algılamışlardır. Levenson (2014) nun yaptığı çalışma ise çokuluslu firmaların gelişmekte olan piyasalara girerken yüzleştiği konular, örgüt tasarımı, yetenek stratejisi ve iş stratejileri konularına dikkat edilmesi gerektiğini savunmuştur. Bu savunmayı karşı çok az örgüt stratejik yönetim içerisinde yetenek stratejilerini bütünleştirme yoluna gitmiştir. Charan ve Bossidy (2002:142) iş stratejilerinin başarı ile yürütülmesinde önemli bir faktör olarak yetenek süreçlerine işaret etmiştir; strateji ve üretimle bağlantılı kılmak adına yetenek süreçleri üzerinde durmuşlardır. Hazırlık aşamasında stratejik yönetim ve yetenek stratejilerinin bütünleştirilmesi gerekir. Bütünleştirme sürecinde örgütsel yapabilirliklere özgü bir yetenek deseninin oluşturulması ve geliştirilmesi önem taşımaktadır. Bunu gerçekleştirirken ortak köprü insan kaynakları stratejileridir. Üst şemsiye olarak insan kaynakları stratejilerinin altında bütünleştirmeyi örgüt içerisinde paylaşılan yetkinlik modelleri ile veya insan kaynakları kuralları, felsefesi, politikaları ve alt süreç/sistemleri yolu ile kurulması akılcıl olur. İnsan kaynakları "stratejik" role daha fazla yöneldikçe yeteneklere de daha dar/yoğun bakış açısı getiren "farklılaştırıcı" yaklaşım getirilmesi de kaçınılmazdır.

Scullion, Collings ve Caligiuiri (2010:106) küresel ölçeği de ekleyerek örgütsel stratejik önceliklere ulaşma da zorunlu roller olarak stratejik rolleri görürken, bu roldeki en iyi çalışanları cezp etmek, seçmek, geliştirmek ve elde tutmak amacı ile oluşturulan tüm örgütsel faaliyetlere yetenek yönetimi tanımını getirmişlerdir. Yetenek yönetimi tanımlarına bakarsak, doğru zamanda doğru yerde doğru kişileri yerleştirilen stratejik olarak liderlik yeteneklerini yönetmek (Sloan, Hazucha ve Van Katwyk, 2003:236), insan sermayesi motoru yolu ile yetenek arzı, talebi ve akışını yönetmeyi içerir (Pascal, 2004:9), örgütsel etkinlikte yeni bir yol veya hem insan kaynakları hem de iş planlamasında bütüncül ve stratejik yaklaşım (Ashton ve Morton, 2005:30), örgüt boyunca yetenek akışının stratejik yönetimi (Duttagupta, 2005:2), gelecekte bir zamanda liderlik rollerine yönelme potansiyeline sahip kişilerin örgüt tarafından bulunması ve geliştirilmesi sürecine işaret eder (Jerusalim ve Hausdorf, 2007:934).

$\mathrm{Bu}$ tanımların ortak noktası örgütün gelecekte başarılı olmasının temel koşulu sahip olduğu insan kaynağının kalitesi ve derinliğinden geçmesidir. Performans ve yetenek kavramına göre yapılan yetenek ve yüksek potansiyelli olarak belirleme ve siralama yoluna gidilmektedir. Bunun temelinde ise rekabetçi avantajın özünde yer alan müşterilere bakış açısı ile farklılaştırma ve pazarların bölümlenmesinin aynısının yeteneklerde yaşandığını rahatlıkla ifade edebiliriz. 


\section{Yüksek Potansiyelli Çalıșanlar}

Hay Group (2008) a göre, potansiyel kişilerin uzun vadeli kişisel gelişim kapasitesi ve olasıl raydan/yoldan çıkarıcıları dikkatte alarak kişilerin mevcut yapabilirlikleri ve olasıl gelecekteki rolleri arasındaki uyumdur. Grup kısa vadeli uyumluluk veya uzun vadeli potansiyeli dikkatte almada kişinin hazır, gönüllü ve yetenekli olma kavramlarının değerlendirilmesi gerektiğini önermektedir. Ready, Conger ve Hill (2010) in yüksek potansiyeller üzerine yazdığı en iyi makalelerden biri olarak kabul edilirken, bu sınıflandırmada farklı çalışma koşullarına göre akranlarına göre sürekli ve önemli ölçüde olağanüstü performans sergilemekte, üst performansa ulaşırken sergiledikleri davranışlar örnek oluşturacak biçimde örgütlerin kültür ve değerlerini yansıtmaktadır. Ayrıca akranlarına nazaran daha hızlı ve etkin olarak örgüt içerisindeki kariyerlerin de gelişme ve başarmada güçlü bir kapasiteye sahiptirler. Örgütün geleceğine önemli katkıda bulunan bu grubun örgüt içerisinde kalacağının bir garantisi de bulunmamaktadır.

Kets de Vries (2012) ise buna yıldız performans gösterenler olarak yaklaşırken yıldızların çatışmaları yönetmek için bir yeteneğe sahip olduklarını, bunun ise zorlu bir fikir veya hedef olduğunu, gerçek yıldızların davranışsal veya mental yeteneklere bütünsel ve parçalara ayırıcı bir düşünce biçimine, denetimci ve özgür bırakıcı anlayışa, iyimser ve gerçekçi olduklarına, içe ve dışa dönük olduklarını ve kısa ve uzun vadeli hedefleri yürüttüklerini ifade ederken aslında bir "çelişkiler" yumağı olduğunu söylemektedir. Silzer ve Church (2010:222) ise yüksek potansiyel tanımında roller, örgütsel seviyeler, rol ve sorumluluk genişliği ve performansı kayıtlarının dikkatte alındığı, tanımlama konusunda örgütler arasında bir mutabakat olmadığını, bunun temel nedeninin ise kimlerin bu grup içerisinde yer alacağıdır. Yeteneğe bu elit bakış açısı ile bağlı1ıkta bir azalma, daha fazla iş-yaşam dengesi talep etme, motivasyon kayıpları ve sonuçta artan devir hızı bu süreçte yaşanabilecek olumsuzluklar arasindadır.

Lombardo ve Eichinger (2000) potansiyel kavramının içerisinde performans göstermede yeni yetenekleri öğrenmeyi de dahil etmiştir. Öğrenme çevikliğine, insani çeviklik, sonuçsal çeviklik, zekasal çeviklik ve değişim çevikliği gibi dört farklı bakış açısı getirmiştir. Yukarıda ifade ettiğimiz üzere öneminin defalarca vurgulanmasına, bu konuda önemli zaman ve para kaynakları ve harcanmasına rağmen örgütler kilit pozisyonları doldurmada hala zorlanmaktadır. Yetenek havuzları ve hatlarının yeterli etkinlikle doldurulmadığı ve işletilmediğidir (formal tanımlanmış prosedürleri olmasına rağmen), bunun sonucunda ise en büyük tehlike olan örgütlerin büyüme ve gelişme arzusu ile bu arzuyu gerçekleştirecek yetenek profillerindeki niteliksel ve niceliksel yetersizlik arasındaki makas gün geçtikçe artmaktadır. Bu noktada Ready ve Conger (2007), yetenek yönetimini örgütün en tepesinde başlayan ve şirket kültürüne nüfuz eden bir tutku olması gerektiğini, lider geliştirmenin daha fazla bir stratejik süreci içermesi gerektiğini vurgularken, "yetenek faktörleri" olarak bir yapılanmayı önermektedirler, bunun stratejik ve kültürel hedefleri destekleyici dikkatte yetenek süreçlerine "işlevsellik" ve günlük eylemleri yansıtan yönetimin duygusal bağl1lı̆̆ olan "yaşayabilirlik". Yazarlara göre gelişen iş ihtiyaçlarını karşılamada hızlı olarak pozisyonları doldurma ve kilit çalışanları elde tutma ve geliştirmeye bu iki kavrama olanak tanıdığını ifade etmişlerdir. Örgütlerin performansı geniş ölçüde insanlar ve görevler arasındaki uyuma bağlıdır. Bu açıdan bakıldığında görev gereksinimleri ile kişilerden bu görevler karşısında ne beklendiğini netleştirmek önem taşımaktadır. Charan, Barton ve Carey ,2015) çoğunlukla insan kaynakları süreçlerinin benzer biçimlerde tüm çalışanlara eşit ölçüde davranma ve bakma eğiliminde olduklarını, yazarların gözlemine göre örgütlerdeki $\% 2$ çalışanın işi yönlendirmedeki etkisinin \%98 olduğunu, liderlerin yetenekleri ve görev gereksinimleri arasındaki açıklı̆̆n iç paydaşlar için sorun yarattığını, ilk başlarda 
davranışsal veya yetenek arasındaki açıklığı tanımlamada üst düzey insan kaynakları yürütücülerinin üstlendiğini, bu grubun özellikle bu \%2 lik kısım içerisinde yer aldığını ve bunun da görev gereksinimlerinin değiştirilmesine yol açtığını ifade etmişlerdir. Bu açıdan bakıldığında örgütte en büyük farklılık yaratacak rolleri tanımlama ve hedefleri iyi bilmek gerekir, bu gereksinimi mevcut ve gelecekteki örgütsel yapabilirlikle sürekli sorgulamak gerekir, ayrıca bu kişilerin elde tutulması için ödül yapısı ile yetenek stratejileri arasında bağ kurulmalıdır. Bağ yeteneklerin elde tutulması ile doğru orantılıdır.

Michaels ve arkadaşlarının (2001:38) doğru bir tespit ile belirlediği yetenek zekasının yaratılması için işinizde kazanan olmak için en iyi insanlara sahip olmaya inanmak, yetenek havuzunu kuvvetlendirmenin işimizin en önemli parçası olduğuna inanmak, yeteneklerin sürekli olarak gözden geçirilmesi gerekir. Stratejik yetenek gereksinimlerinin belirlenmesinin yanında, gereksinilen yetkinlikler karşısında bireylerin değerlendirilmesi, yeteneklerin yetkinliklerini örgütsel yapabilirlikler doğrultusunda geliştirmek ve kilit yetenekleri elde tutmak gerekir. Yetenek sürecinin genel insan kaynakları ve iş stratejileri ile bütünleştirilmesi ve birlikte ele alınması yetenek yönetiminden elde edilecek "değeri" artıracaktır. $\mathrm{Bu}$ değerin tam kalbinde yukarıda belirtilen yetenek zekası kültürünün benimsenme derecesi yatar. Bu bağlantının kurulma derecesi ve sıklığ örgütsel performansı yanında getirecektir. Örgütlerin yüzleştiği en önemli sorun olarak karşımızda durmaktadır. SHRM nin Globalforce ile yaptığı 2015 yılı çalışan tanınma gözleminde çalışanları elde tutma/devir hızı (\%40) ve çalışanların tutku (\%39) ile bağlanması insan kaynakları profesyonellerince şu anda yüzleşilen en önemli örgütsel zorluk olarak bulunmuştur. Başarılı bir çalışan tanınma programında çalışanları elde tutma, devir hızı ve tutku ile işe bağlanmaya etkisi olabileceğini, üst düzey yeteneklerin elde tutulmasına yardımcı olacağı da saptanmıştır. Çalışanların elde tutulması ve devir hızına zorunlu bakış açısı 2012 yılında $\% 35,2013$ y1lında $\% 33$ ve 2015 y1linda ise $\% 40$ a yükselecektir. TowerWatson unun 2014 yılında yaptığı araştırmada işveren ve işçi bakış açısı ile elde tutmadaki en büyük iki faktör sıralamada aynı seviyede çıkmıştır; temel ücret ve kariyer ilerleme firsatları. Küresel ekonomilerin iyileşmesi ile örgütler çalışanların terfileri, yan haklar ve ücret artışları önerileri, elde tutmaya odaklanma konusunda daha esnek olmaktadırlar. Bu soruna bakışta devir hızı ve nasıl yönetildiği önem kazanmaktadır.

Frank, Finnegan ve Taylor (2005), elde tutmayı iş hedeflerine ulaşmada işverenin arzuladığı çalışanlarını elde tutma çabası olarak tanımlamıştır. Yazarlar elde tutma ve tutku ile bağlanmayı (adanmışlık) birlikte ele alarak iyileştirmek için geleneksel ve yenilikçi çözümler olarak işgücünün bölümlendirilmesi, bu bölümlerdeki kişilere özgün ödül programlarının tasarlanmasını, değişken ödeme sistemine geçilmesini, takım üyeleri ve liderleri arasında güvene dayalı bir ilişkinin kurulmasını, takım üyelerinin özgüvenlerinin artırılmasını, etkin iletişimin oluşturulması, bireylerin ihtiyaçlarını tanıma, anlama ve uyarlanmada daha esnek olunmasını, koçluk ve yetenek gelişimlerine önem verilmesi gibi öneriler geliştirmişlerdir. Mitchell, Holtom ve Lee (2001) , çalışanların örgüte iliştirilmesinde üç önemli araç olarak bağlantı, uyum ve fedakarlık yapma biçiminde tanımlama yapmıştır. Bağlantıyı kuvvetlendirmek için mentorluk sunma, takım çalışması tasarlama, takım bağlılığını belirleme ile kuvvetlendirileceği, uyumu kuvvetlendirmek için ise işe alım esnasında görev ve şirket hakkında gerçekçi bilgiler vermek, seçimde görev ce örgütsel uyumu bütünleştirmek, girişimci değerleri ve kültürü hakkında açı bir sosyalizasyon ve iletişim sunma sağlanır. Fedakarlığı kuvvetlendirmede ise kişiyi finansal teşviklerle bağlantılandırma ve özgün teşvikler sunulur. İnsan kaynakları yöneticileri doğru bir elde tutma girişimini geliştirmede olduğu kadar devir hızının doğasını ve nedenlerini sürekli olarak teşhis etmeye cesaretlendirilmelidir. Elde tutmayı da geniş bir yetenek yönetimi stratejisi ile bütünleştirilmelidir. Örgütlerin özgünlüğü de unutulmamalıdır, hatta 
bunu aynı örgütün farklı bölümleri, görev tipleri ve coğrafik yerleşimler ve bireylere kadar indirgenebilir. $\mathrm{Bu}$ ise elde tutma sistemlerinin farklı desenleri ve renkleri içinde barındırdığı anlamına gelir.

Stell, Griffeth ve Hom (2002), bir elde tutma planı geliştirmişlerdir. Plan devir hızının bir sorun olup olmadığını tartışmayla başlamakta, insanların neden ayrıldıklarını, kimlerin ayrıldığını ve bunun fayda ve maliyetlerinin ne olduğu tartışılması ile elde tutma da hedef geliştirmekle, ikinci aşamada çıkış görüşmeleri, çalışanların gözlemlenmesi, odak grup çalışmaları ve dışarıdan veri toplama ile hedeflenen stratejiler ve geniş temelli stratejiler ile üçüncü aşama da uygulama ve değerlendirme gerçekleştirilecektir. Elde tutma girişimleri arasında baz/temel ücret artışlarının piyasa koşullarına göre düzenlenmesi, çalışma çevresinin yeniden ele alınması, terfi ve kariyer geliştirme firsatları, Pazar payının üzerinde ödeme yapılması, özel eğitim ve geliştirme firsatları sunulması, ikramiye programlarının geliştirilmesi yer alır (Heneman ve Judge, 2006:58; Parus ve Handel, 2000). Bu girișimler yetenek düzlemindeki kaymalar nedeni ile çalışanın değerini korumayı artan ölçüde zorlaştırmaktadır. SHRM (2008:27) elde tutma planı için yaptığı öneriler arasında örgütteki devir hızını yönlendiricilerinin buluntularının araştırılması, örgütteki devir hızının yönlendiricilerinin yönetilebilirliği ve önemli olanların teşhis edilmesi ve son olarak örgütlerin özgün ihtiyaçlarını karşılayacak biçimde elde tutma stratejilerini tasarlamak, hayata geçirmek ve değerlendirmek. Örgütler çalışanların beklentileri ile potansiyellerinin açığa çıkarılmalarında yardımcı aynı zamanda örgütün ihtiyaçlarını da dikkatte alacak biçimde "proaktif" bir yetenek yönetimi anlayışını benimsemelidirler.

Lisican (2013) tutku ile bağlanmanın/adanmışlığın üst düzey bir yürütücü olduğunu, yeteneğe olan talebin artması ile yetenekli liderlerin müşteri gözlemlerinde olduğu gibi çalışanın bağlılığı anketlerinin sorumluluk ve önemini aynı seviye de görmelerinin gerektiğini savunmaktadır. Oldham (2013) elde tutmanın karmaşık bir konu olduğunu, işe alım sürecine başlamadan önce konunun düşünülmesi gerektiğini, etkin bir elde tutma stratejisini oluşturmada şirketlerin bir görev veya kariyer değişimi üzerinde durduklarında bir izleme ve eleman bulma konusuna ihtiyaç duyulacağını. Ayrıca performans yönetimi ve yedekleme planlamasının da ötesinde değerlendirilmesi gereken bir örgütsel yaklaşım olduğunu, bunun da çalışan kariyer hedefleri ve devir hızı konusun da önemli öngörüler sağlayacağını ifade etmektedir. Yetenek yönetimi sürecinin insanlar yolu ile rekabetçi avantaj kazanma olduğunu düşünürsek şu anda ve gelecekte strateji sunacak doğru zamanda ve doğru roldeki doğru insanları bulmak ve elde tutma ile ilgilidir. Mercer in (2014) yaptığı araştırma da örgütlerin $\% 73$ 'ü kritik yeteneği yüksek potansiyelli, \%62'si yüksek performansl1, \%40-45'i görev temelli olarak ve \%28'i yetkinliklere dayalı olarak tanımlanmışlardır, araştırmaya katılan örgütlerin \%62'si dışarıdan ve içeriden aday temini arasında bir denge kurdukları, örgütlerin \%58'si kritik yetenekleri cezp etme, elde tutma ve tutku ile bağlanmalarında bir işveren markası olduklarını, \%49'u kritik yetenek statüsünü örgüt içerisinde tanımladıkları, \%34'ü insan kaynakları sistemlerinde kritik yetenek statüsünü takip ettikleri ve \%68'si yıllık olarak kişinin yetenek listelerini güncellediklerini ifade etmiş̧lerdir. Yapılan araştırmanın bir diğer çarpıcı sonucu kritik yeteneklerde istenen yetkinlikler üzerinedir. Davranışsal anlamda iletişim, karar verme, liderlik, örgütsel farkındalık/öngörü ve ilişki oluşturma, teknik yetkinlikler olarak iş bilgisi, eğitim, sektör bilgisi, buluşçu/yaratıcı düşünme ve stratejik planlama yetkinlikleri öne çıkmıştır.

KPMG (2013) kritik roller için kurum içi adayların derinliğinin bulunmamasının gelecekteki liderlik için yetersiz kariyer yollarının bulunmasına, kilit çalışanların elde tutmadaki zorlukları, iş değeri sunmadaki kritik roller konusundaki netlik yoksunluğunu, yakın gelecekteki işler tarafından ihtiyaç duyulan yetenek ve yapabilirlikleri geliştirmedeki 
başarısızlıklar ve üst düzey yetenekler için zorlayıcı geliştirme firsatlarının eksikliğini yapabilirlik ve kapasite ile ilişkili yetenek riskleri içinde değerlendirilmelidir. Net olan sonuçlardan biri; yetenek yapabilirliği ile örgütlerin ayakta kalması ve yaşamlarını sağlıklı olarak yürütebilmesi arasında doğrusal bir bağlantı söz konusudur. Önemli olan kısım örgütlerin yönetimi kavramını iş öncelikleri arasında nereye koydukları ve iş yapma biçimlerine nasıl yaydıklarıdır. Örgüt içi uyum, örgüt kültürü ile uyum ve örgütün stratejisi ve uzun vadeli stratejik uyum derecesinin yüksekliği yetenek yönetiminin taklit edilemeyen bir yönlendiricisi konumuna yükselmesini sağlayacaktır. Gochman ve Storfer (2014) yukarıdaki bağlantıyı ancak \%3'lük bir çalışan grubunun farkında olduğunu, bir insan kaynakları planının sürekli değişen iş stratejisi ve gelişiminin tüm özelliklerini destekleme üzerine odaklandığında gerçek bir yetenek stratejisi olacağını, bunun da iş stratejisini yürütme de çalışanların tutku ile bağlanmalarını ve aktif olarak ilişkilendirmeye yardımcı olacağını söylemişlerdir. Haid 'in (2012) ifade ettiği gibi yeniçağ insan çağıdır. İnsan potansiyeli değişim için katalizör olabilir ve ekonomik, politik ve sosyal gelişism için küresel bir güçtür. Yazar buna "talentism" ismini vererek buna yeni kapitalizm demektedir.

\section{4. Örgütlerin Sahip Olduğu Yeteneklerin Kalitesi ve Derinliği Araştırması}

Araştırmada kapalı uçlu sorulardan oluşan önem sırasını belirlemeye yönelik 4 (dört) soruluk anket hazırlanarak alan araştırması yapılmıştır. Bu alan araştırması, yetenek yönetimi ile öncelikli önemli konuları belirlemeyi hedeflemiştir. Bunun yanında odak grup görüşmeleri yapılmıştır. Bu görüşmeler farklı özel işletmelerde görev yapan insan kaynakları çalışanları davet edilerek, oturumlar yapılarak gerçekleştirilmiştir. Yapılan bu çalışmalar doğrultusunda, araştırma kapsamında aşağıda sırasıyla araştırmanın problemi, amacı ve önemi, yöntem ve son olarak bulgular ve yorum ele alınmıştır.

\subsection{Araştırmanın Problemi, Amacı ve Önemi}

Araştırmanın problemi: “Örgütlerin sahip olduğu yeteneklerin farkında olup olmadığı? Yetenek Yönetimi ile ilgili mevcutta ne gibi uygulamalar yaptıkları? Yeteneklerinin kalitesi konusunda ne düzeyde bilgi sahibi oldukları?" sorularıdır.

Araştırmanın amacı: İşletmelerin sahip oldukları yeteneklerin farkında olup olmadığını belirlerken, eğer farkında ise kalitesi ve derinliğinin ne ölçüde olduğu, bu doğrultuda işletmelerde yetenekler konusunda yapılan uygulamalar neler olduğunu, yüksek potansiyelli çalışana bakış açılarının neler olduğu ve son olarak da yetenek yönetimi programlarının olup olmadığını incelemektir.

Araştırmanın önemi: İşletmeler açısından yetenek yönetimi programlarının uygulama amaçları belirlenecek, yetenek programına alınacak kişilerde ne gibi özellikler olması gerektiği belirlenecek, yetenek yönetimi programı ile alınmak istenilen sonuçlar belirlenecek ve son olarak program uygulanırken karşılaşılan zorluklar belirlenecektir. Bu doğrultuda araştırma sonucunda elde edilecek bulgular, örgütlerin elindeki yeteneklere bakış açısını, bunlara uygulayacakları programlardaki ve yetenek seçimindeki zorlukları ve yeteneklerin nasıl değerlendirdiğinin üstüne yoğunlaşmıştır.

Araştırmanın sınırlılıkları ise zaman ve maliyet kısıtları nedeniyle sınırlı sayıda işletme yöneticisi ile yapılan görüşmeler ve anketlerle yapılmasıdır. Çalışma sadece 22 işletmenin yöneticisi ile sınırlı tutulmuştur. Bu yüzden, araştırma sonuçlarına dayanarak İzmir ve Manisa'da faaliyet gösteren tüm işletmeler için bir genelleme yapmak doğru olmaz. 


\subsection{Yöntem}

Yöntem alt bölümü, verilerin toplanması ve verilerin analizi kısımlarından oluşmaktadır. Çalışmada bilimsel araştırmalarda başvurulan ana metotlardan üç tanesine yer verilmektedir. Birincisi, temel araştırma tekniğidir. Burada çalışmanın teorik yapısını oluşturmak için konu ile ilgili ulusal ve uluslararası bilimsel çalışmalardan yararlanılmıştır. İkinci yöntem ise, teorisi oluşturulan çalışma ile ilgili yapılan alan araştırmasıdır. Alan araştırması için kapalı uçlu sorulardan oluşan bir anket hazırlanmıştır. Anket dört (4) adet önem sırasını belirten sıralama sorusundan oluşmaktadır. $\mathrm{Bu}$ sorular, yetenek yönetimi ile öncelikli önemli konuları belirlemeyi amaçlamıştır. Üçüncü yöntem ise, nitel bir veri toplama yöntemi olan odak grup görüşmesi kullanılmıştır. Odak grup görüşmesinde, görüşmeyi yapan kişi küçük bir grup insandan (genellikle dört ile sekiz kişi arası), bir dizi sorun hakkında düşünmesini ister. Katılımcılar, aynı fikirde olabilirler ya da olmayabilirler; görüş birliği ne gerekli ne de arzu edilen bir şeydir. Hedef, katılımcıların diğerlerinin görüşlerini duyabildiği ve buna göre kendi görüşleri üzerine düşünebildiği sosyal bir ortamda, insanların bir konu ya da konular hakkında gerçekten ne düşündüklerini kavramaktır. Odak grup görüşmesi bir tartışma olmayıp problem çözme veya karar alma grubu da değildir (Büyüköztürk vd., 2013:146). Bu nedenle katılımcıların duygu ve düşüncelerini anlamak, nicel görüşmelerden farklı olarak yüzeysel değil daha derin bilgi edinmek esastır (Kuş, 2009:87).

Çalışma grubu, PERYÖN Türkiye İnsan Yönetimi Derneği Ege Şubesi üyesi insan kaynakları yöneticileri ve uzmanlarıdır. Kurumlarıyla ilgili mevzuatlar ve yürütülen çalışmalar hakkında diğer çalışanlara göre daha çok haberdar olacakları varsayımıyla belirlenmiştir. PERYÖN Türkiye İnsan Yönetimi Derneğine kayıtlı kurumlara mail atılmış, dönüş yapan işletmeler arasından 22 yönetici ve uzman davet edilerek odak grup çalışması ve anket uygulaması yapılmıştır. Araştırmaya katılan yönetici ve uzmanları temsil ettiği İzmir ve Manisa'da faaliyetlerini sürdüren 18 özel işletme ve 4 kamu kurumu, örgütlenmesi yaygın, köklü tarihsel geçmişi olan, geniş kitlelere hizmet veren ve kısmen personel sayısı fazla olan kurumlardır.

\subsubsection{Verilerin Toplanması}

Odak grup görüşmesi, insan kaynakları çalışanlarının uygun olduğu bir zamanda Ege Üniversitesi İktisadi İdari Bilimler Fakültesi dekanlık toplantı salonunda yapılmıştır. Görüşme, dört ayrı oturumda farklı kişilerle yapılmıştır. Görüşmeye başlamadan önce, görüşmenin not alınarak ve ses kayıt cihazıyla kaydedilmesi gerektiğine ilişkin katılımcılara bilgi verilmiş, izinleri alınmıştır. Katılımcıları tanıtır isim ve unvanlarını yazan kartlar hazırlanarak önlerine konmuş ve çalışma grubu üyelerinin birbirlerini rahatça görebileceği ve iletişim kurabileceği bir oturma düzeniyle görüşmeye başlanmıştır. İlgili anket ise görüşmeler sonunda, ilgili katılımcılara görüşlerini belirlemek açısından düzenletilmiştir.

Öncelikle grup üyeleri birbiriyle tanıştırılmış, görüşmenin amacı, süresi hakkında bilgi verilmiştir. Araştırma için elde edilen bilgilerin başka bir amaçla kullanılmayacağ belirtilmiştir. Görüşmede insan kaynakları çalışanları çeşitli sorularla yönlendirilmiştir. Sırasıyla görüşlerini bildiren insan kaynakları çalışanlarına, konuşmanın akışına göre ilave sorular sorulmuş, zaman zaman çalışanların birbirlerine soru cevap yöneltmelerine izin verilmiştir. Odak grup görüşmesi, tüm grup üyelerinin aktif katılımıyla, planlanan süre içerisinde tamamlanmıştır. 
Görüşme verilerinin analizinde amaç, elde edilen görüşme verileri ile araştırma konusunu ilişkilendirmektir. $\mathrm{Bu}$ işlem yapılırken, "Görüşme verileri araştırma sorusuna ilişkin literatürü destekliyor mu?", "Görüşmenin anlatmak istediği ana tema nedir?" gibi soruların göz önünde bulundurulması yararlı olacaktır (Büyüköztürk vd., 2013:163,164). Odak grup görüşmelerinin çözümlenmesi, nicel çalışmalara göre daha az yapılandırılmış, daha çok açılayıcıdır. Sayısallaştırma tercih edilen ve uygun bir yöntem değildir. Odak grup görüşmelerinde genelleme kaygısı olmadığından, sayısallaştırmaya da gerek yoktur. Sayısal veriden çok, bireysel düşüncelerin farklılıklarının nasıl verildiği önemlidir. Ayrıca, araştırmacının öne sürdügünün aksine, ortaya çıkan farklılıkları sunmak bütün nitel araştırmalarda olduğu gibi, burada da çok önemlidir. Verilerin analizinde içerik analizi en uygun yöntemdir. Veri analizinde en iyi yol, kayıs sırasında ya da sonrasında çözümleme yapılırken, belli başlıklar altında anahtar temaları belirlemektir. Raporda genel olarak temalara göre belirlenen algılar yer almalıdır. Analiz yaparken ve raporlaştırırken konuşma dilinin olduğu gibi kalmasına dikkat edilmelidir (Çokluk vd., 2011:105). Ayrıca, görüşmeler sonunda 4 sıralamalı sorudan oluşan anket dağıtılarak farklı bir açıdan görüşler alınmaya çalışılmıştır.

\subsection{Bulgular ve Yorum}

Bulgular ve yorum kısmında ilk olarak odak grup çalışmasının çözümlemesi verilecek, ardından anket sorularının analizi yapılarak sonuçlandırılacaktır. Odak grup çalışmas 22 işletmenin insan kaynakları yöneticiler/çalışanlarına yapılmıştır. Gelen katılımcılara aynı zamanda 4 soruluk sıralama soruları olan bir anket uygulanmıştır.

Odak Grup Çalışması Çözümlemesi: İnsan kaynakları profesyonellerinden 3 kişi kapsayıcı yaklaşımla yetenek kavramını herkes bir yetenektir olarak tanımlarken, 19 kişi dışlayıcı yaklaşımda tanımlamakta ve yeteneklerin ayırt edici özelliklere sahip kişiler olduklarını savunmaktadırlar. Katılımcılardan 4'ü yeteneği "şirketin hedeflerini gerçekleştirmesine yardımcı olabilen kişiler" olarak tanımlamıştır. 4 kişi şirketin stratejisine göre yetenek kavramının değişebileceğini savunmuştur. Bunun dışında yetenek; "doğuştan gelen kabiliyetleri olan, gelişime, yeni şeyler öğrenmeye ve değişime açık, başkalarının görmediğini görebilen, ekip arkadaşları için rol model olan, departman içi ve departmanlar arası ilişkilerini yönetebilen, şirket değerleriyle uyum sağlayabilen istekli kişiler" olarak tanımlanmıştır. Yüksek potansiyelli kavramı ise katılımcıların çoğu tarafından yetenek kavramından farklı görünmezken, diğerleri yüksek potansiyelliyi yetenekten ayrı görerek "insanların zaman içinde gelişebilmesinin karşılı̆̆ı", "kişinin yeteneğini sergileyebilmesi", "yeteneği olmayan fakat becerisi olan kişiler", "şirketin hedeflerini gerçekleştirebilecek kişiler", "yeteneği performansa dönüştürebilen kişiler" şeklinde tanımlar getirmişlerdir.

Katılımcıların 10'u çalıştıkları şirketlerde yetenek programlarının uygulandığını söylerken, 10'u herhangi bir yetenek programı uygulamadıklarını belirtmişlerdir. Yetenek programlarının olmamasının nedenleri arasında şirketin öncelikleri arasında yer almaması; sektörel olarak yöreden istihdam zorunluluğu gibi bir kısıtın olması; çok uluslu şirketlerde yurtdışına bağlı olarak çalışılması; şirket için bu tür yapılanmanın çok erken olması; sistematik, formel bir yapının olması sonucu sistemin verimli çalışmayacağı gibi nedenler bulunmaktadir.

Yetenek yönetimi programlarının uygulama amaçlarında en çok yedekleme yapmak, çalışan motivasyonunu yükseltmek ve elde tutmayı kolaylaştırmaktan bahsedilmiştir. Bunun yanında şirkete para kazandırmak, şirket hedeflerini gerçekleştirmek, çalışanlarda farkındalık yaratmak, net bakış açısı kazandırmak, şirket stratejisinin gereklerine uygun kişiler 
yetiştirmek, bağlılığ 1 arttırmak, doğru kişileri doğru pozisyon ve işlere yerleştirmek, eğitim gelişim kaynaklarını dağıtabilmek ve çalışan devir oranını azaltmak da katılımcılar tarafindan yetenek yönetimi programlarının amaçları arasında görülmektedir.

Yetenek yönetimi programının sahibi katılımcıların çoğuna göre üst yönetim/genel müdür, hayata geçiren ise insan kaynakları olmalıdır. Bunun yanında süreç sahibinin herkes olması gerektiğini söyleyen veya güçlü bir insan kaynakları departmanı olması gerektiğini söyleyen katılımcılarımız da bulunmaktadır.

Katılımcılar yetenek yönetimi programının içerisinde eğitim - akademi programlarının, eğitmen veya danışman raporlarının, gelişim planlarının, yol haritasının, yetenek havuzlarının, koçluk - mentorluk uygulamalarının ve koçluk eğitimlerinin, rotasyonun, $360^{\circ}$ performans değerlendirmenin, projelerde öncelik verilmesinin ve geribildirimlerin olması gerektiğini söylemektedirler.

Katılımcılardan 17'si çalışanın "yetenek" ya da "yüksek potansiyelli" olduğunu bilmesi gerektiğini, sürecin şeffaf olması gerektiğini savunurken, 4’ü bilmemesi gerektiğini ya da şeffaf olmaması gerektiğini savunmakta, 1'i ise duruma göre karar vermemiz gerektiğini düşünmektedir. Bilmemesi gerektiğini savunanlar özellikle yetenek yönetimi programı dışındakilerin bunu öğrenmesi durumunda demotive olacaklarını düşündüklerini belirtmektedirler.

Katılımcılar yetenek programına alınacak kişilerde aranacak özellikler arasında liderlik gücünün, takım liderliği yeteneğinin, başkalarını etkileme ikna etme yeteneğinin, gelecek odaklılığın, olumlu performans değerlendirmeye sahip olmalarının ve kişinin değerlerinin o şirketle uyumlu olmasının önemli olduğunu öngörmektedirler.

Yetenek ve yüksek potansiyelli olanlar için kişisel gelişim planları hazırlanması, koçluk imkânı ve mentorluk sisteminin sağlanması katılımcıların sundukları ve düşündükleri önemli gelişim fırsatları arasında yer almaktadır. Bunun yanında yurtdışı eğitimleri, teknik eğitim imkânları, diğer çalışanların katılabileceği eğitimlerden farklı eğitimler alabilmeleri için bir ücret paketi de ayrılabiliyor. Özellikle katılımcılarımızın çoğu eğitim desteğini yetenek ve yüksek potansiyelliler önemli gelişim firsatları arasında görmektedirler.

Katılımcılarımız genel olarak yüksek potansiyelli çalışanları ödüllendirme programının içeriğinde performans bonusları, eğitim desteği, ücret zammı ve kurum içi terfinin olması gerektiğini düşünmekteyken, katılımcılarımız arasında gelişim imkanlarının yeterli olduğunu; bonusların ve artı ücretlerin kısacası parasal bir ödül sisteminin olmaması gerektiğini düşünenler de bulunmaktadır.

Katılımcılar şirketteki her pozisyon için bir yedek olmadığını söylemektedirler. Yerinin doldurulmasının zor olduğu, katma değer yaratan pozisyonlar kilit pozisyon olarak tanımlanmakta ve yetenek yönetimi programı ile özellikle kilit pozisyonlar için yedekleme yapmak en çok istenen sonuçlar arasında yer almaktadır. Bunun dışında kademe geçişlerini yapabilmek, yönetici yetiştirmek, elde tutmayı sağlamak, şirketin yaşaması, devam etmesi için yetenekleri yetiştirmek de elde edilmek istenen sonuçlar arasında görülmektedir.

Yetenek yönetimi programlarının etkinliğini ölçen ölçütler arasında en çok çalışan memnuniyet oranı, işgücü devir oranı, devamsızlık oranları, açık pozisyonu doldurma süresi yer almaktadır. Bunun yanında dengelenmiş puan kartı, eğitim gerçekleştirme oranı, işe alım maliyeti, yetenek yönetiminde yatırımının geri dönüşü (talent management return on investment), çalışan bağlılı̆̆ , eğitim planı gerçekleştirme oran1, yeni personel işgücü devir oranı, eğitim uygunluk oranı, kadın-erkek çalışan sayısı, yetenek yüzdesi, yetenek işgücü 
devir oranı, kurum içi terfi sayısı, kurumsallaşma oranı, personel maliyeti ve eğitim sayısı da kullanılan ölçütler arasında bulunmaktadır.

Anket Analizi: Odak grup çalışmasına gelen 22 katılımcıya yetenek yönetimi programlarını göz önünde bulundurarak aşağıda sonuçları verilen sıralamaları yapmaları istenmiştir. En önemlisine 1, ardından gelenlere 2, 3.. vererek sıralama yaptırılmıştır. Bu doğrultuda, toplamda en düşük puanı alan ifadenin en önemli olduğu sonucuna varılmak istenmiştir. Önem sırasına göre yapılan sıralamalar aşağıda tablolarda verilmiştir.

Tablo 1'de görüldüğü üzere; "yetenek yönetiminin uygulama amaçları" önem sırasına göre sıralandığında en önemli amaç olarak yeteneklerin şirket içinde elde tutulması gösterilmiştir. Katılımcılar ilk olarak yetenek olarak gördükleri ve ileride beklentileri olan çalışanlarının işletmede tutmayı önemli bir amaç olarak görmüşlerdir. Bunun nedeni olarak, yetenekli çalışanların zor bulunan ve işletmeler için gelecekte önemli insan kaynağı olan kişiler olarak kaybedilmesinin yetenek havuzlarında ve işletmenin gelecek planlarında sorunlar yaratabileceği söylenebilir. Katılımcılar diğer önemli cevap olarak yedekleme yönetiminin temelini oluşturmasını belirtmiştir. Yetenekli çalışanlar işletmelerin yedeklemesinde önemli bir noktayı oluşturduğundan, katılımcılar yedekleme yönetimi açısından yetenek yönetimi programının uygulanmasının gerekliliği üzerinde durmuşlardır. Bu iki faktör toplam puanlara da bakıldığg gibi diğer belirtilen unsurlardan belirgin şekilde önemli bir unsurdur.

Üçüncü önemli unsur olarak gözüken çalışanları motive etmenin bir yolu olması orta düzeyde yetenek yönetimi programlarının uygulama amaçlarından biri olarak belirlenmiştir. Buradan anlaşılacağı gibi, yetenek yönetiminin çalışanları motive etmenin bir yolu olduğu konusunda anlamlı ölçüde önemli olmadığı belirlenmiştir. Kültürel uyumun daha kolay sağlanması ve içeriden çalışan temin etmenin daha az maliyetli olması unsurlarının yetenek yönetimi programlarının uygulama amaçlarına etki etmediği belirlenmiştir. İşletmede kültürel uyuma pek etki etmediği düşünülmektedir. Bununla beraber içeriden çalışan temin etmenini de yetenek yönetimi programları amacına etki etmediği açık şekilde belirlenmiştir.

Tablo 1: Yetenek Yönetimi Programlarının Uygulama Amaçları Önem Sıras1

\begin{tabular}{|l|c|c|}
\hline Yetenek Yönetimi Programlarının Uygulama Amaçları & Toplam Puan & Öncelik Sırası \\
\hline Yedekleme yönetiminin temelinin oluşturması & 47 & 2 \\
\hline Yeteneklerin şirket içinde elde tutulması & 43 & 1 \\
\hline İçeriden çalışan temin etmenin daha az maliyetli olması & 89 & 5 \\
\hline Kültürel uyumun daha kolay sağlanması & 81 & 4 \\
\hline Çalışanları motive etmenin bir yolu olması & 70 & 3 \\
\hline
\end{tabular}

Tablo 2'de yetenek yönetimine alınacak kişilerin özelliklerinin değerlendiricileri ile ilgili ifadeler önem sırasına göre listelendirilmiştir. Listelendirilen ifadelere bakıldığında en önemli ifadenin şirket içerisinde oluşturulan değerlendirme merkezlerinde belirlenmesi yönünde ifade olduğu belirlenmiştir. Bu doğrultuda, şirket içinde değerlendirme merkezleri kurulması ve yetenek havuzlarının bu merkezlerde belirlenmesi gerektiği vurgulanmıştır. 
İkinci önemli kıstas olarak iki kavram eşit puanı almıştır. Bunlar yöneticinin değerlendirme sonuçları ve performans yönetimi sonuçlarıdır. $\mathrm{Bu}$ iki kavram işletmelerin yetenek programına alınacak kişilerdeki özellikleri değerlendirmede kullanabilecek diğer yöntemler olarak belirlenmiştir. Kişilik envanterleri ifadesi ise yetenek havuzlarına girecek kişilerin belirlenmesinde en son tercih edilecek unsur olarak belirlenmiştir.

Tablo 2: Yetenek Programına Alınacak Kișilerde Aranacak Özellikleri Değerlendiricileri Önem Sırası

\begin{tabular}{|l|c|c|}
\hline Yetenek Programına Alınacak Kişilerde Aranacak Özellikler & Toplam Puan & Öncelik Sırası \\
\hline Yöneticilerin değerlendirme sonuçları & 58 & 2 \\
\hline Performans yönetimi sonuçları & 58 & 2 \\
\hline Kişilik envanterleri & 62 & 4 \\
\hline Şirket içerisinde oluşturulan değerlendirme merkezleri & 45 & 1 \\
\hline
\end{tabular}

Tablo 3'de yetenek yönetimi programı ile elde edilmek istenen sonuçların önem sırası belirlenmiştir. Tabloda da gözüktüğü gibi stratejiye en fazla katkıda buluna kritik roller için projelerin devamlılığını sağlama ifadesi en önemli ifade olarak belirlenmiştir. Kritik roller için projenin devamlılığı sağlamak açısından yeteneklerin yönetiminin önemi vurgulanmıştır. İkinci olarak yetenek yönetimi programının yetkinlik geliştirme açısından önemli sonuçlar alabileceği belirlenmiştir. $\mathrm{Bu}$ doğrultuda, yetenek yönetiminin yetkinlik üzerinde etkisi olduğu söylenebilir. Elde edilen sonuçlara bakıldığında üçüncü önemli unsurun yetenek yönetimindeki kişilerin motivasyonunu arttırma işlevi olduğu belirlenmiştir. Bunun yetenek yönetimi için diğerlerine göre daha az önemli bir ifade olduğu belirlenmiştir. Son olarak, devir hızı oranları belirlenmiştir. Devir hızı oranları ile yetenek yönetimi programının arasında çok önemli bir bağ olmadığı belirlenmiştir.

Tablo 3: Yetenek Yönetimi Programı İle Elde Edilmek İstenen Sonuçların Önem Sırası

\begin{tabular}{|l||c||c|}
\hline Yetenek Yönetimi Programı İle Elde Edilmek İstenen Sonuçlar & Toplam Puan & Öncelik Sırası \\
\hline $\begin{array}{l}\text { Stratejiye en fazla katkıda buluna kritik roller için projelerin devamlılığını } \\
\text { sağlama }\end{array}$ & 35 & 1 \\
\hline Yetenek yönetimindeki kişilerin motivasyonlarını arttırma & 68 & 3 \\
\hline Devir hızı oranlarını düşürme & 69 & 4 \\
\hline Yetkinlikleri geliştirme & 50 & 2 \\
\hline
\end{tabular}


Tablo 4: Yetenek Yönetimi Programının Uygulanmasındaki Zorluklar

\begin{tabular}{|l|c|c|}
\hline Yetenek Yönetimi Programının Uygulanmasındaki Zorluklar & $\begin{array}{c}\text { Toplam } \\
\text { Puan }\end{array}$ & $\begin{array}{c}\text { Öncelik } \\
\text { Sırası }\end{array}$ \\
\hline Programın beklentilerine tam olarak ulaşılamaması & 70 & 4 \\
\hline $\begin{array}{l}\text { Yetenek yönetimi programında yer almayan kişilerin motivasyonlarını } \\
\text { yüksek tutma }\end{array}$ & 73 & 5 \\
\hline Yetenek yönetimi ile yeteneklerin şirket içinde tutulması & 63 & 3 \\
\hline $\begin{array}{l}\text { Yetenek yönetimi programına katılma ölçütlerinin olmaması veya net } \\
\text { olmaması }\end{array}$ & 61 & 2 \\
\hline Şirket genel politikaları ve stratejileri ile yaşanan uyumsuzluk & 60 & 1 \\
\hline
\end{tabular}

Katılımcılara son soru olarak yetenek yönetimi programının uygulanmasındaki zorluklar sorulmuştur. Verilen cevaplarda en önemli zorluğun şirket genel politikaları ve stratejileri ile yaşanan uyumsuzluk olduğu belirlenmiştir. Ancak, yapılan puanlamaya bakıldığında yetenek yönetimi programına katılma ölçütlerinin olmaması veya net olmaması ifadesinin de en az ilk ifade kadar zorluk olduğu belirlenmiştir. Bununla birlikte yetenek yönetimi ile yeteneklerin şirket içinde tutulması ifadesi de önemli bir ifade olarak belirlenmiştir. Bunların dışında, programın beklentilerine tam olarak ulaşılamaması kavramı dördüncü önemli kavram olarak belirlenmiştir. En önemsiz kavram olarak da yetenek yönetimi programında yer almayan kişilerin motivasyonlarını yüksek tutma ifadesi tercih edilmiştir. Şirket genel politikaları ve stratejilerin arasındaki uyum sorunu insan kaynakları yöneticileri açısından en önemli zorluk olarak ifade edilmiştir. Çünkü, işletme genel politikasıyla uyumsuz bir strateji yetenek yönetiminin uygulanması açısından son derece zorluk çıkarabilecek bir kavramdır. İnsan kaynakları çalışanları ölçütlerin doğru belirlenmesinin veya net olmamasının işletme içinde uyumsuzluk yaratabileceğini son derece önemli bir durum olarak ortaya koymuştur. Yetenekleri elde tutmakta sadece yetenek yönetimi programı ile mümkün olabilecek bir durum değildir. Bu bağlamda yetenekleri elde tutmanın zorluğu da ifade edilmiştir.

\section{Sonuc}

Günümüzde yetenek ve yetenek yönetimi kavramı yöneticilerin ilgilenmek zorunda oldukları öncelikli konulardan biri haline gelmiştir. Yöneticilerin yeteneklere verdikleri önem ve elde tutma çabası konunun önemini daha da artırmaktadır. Buradan hareketle, çağımızın modern örgütlerinde yöneticilerin yetenek yönetimi konusunda bilgi sahibi olması ve bu konuda çalışmalar yapabilecek vasıflara sahip olmaları beklenmektedir. Literatürde yetenek yönetimi konusunda gerçekleştirilen birçok çalışma vardır. Bu çalışmalarda, kavramın önemi ve yetenekli olarak lanse edilen kişilerin nasıl doğru değerlendirilebileceği konuları araştırılmıştır.

İzmir ve Manisa illerindeki faaliyet gösteren işletmelerin insan kaynakları uzmanları ve yöneticileri üzerinde gerçekleştirilen bu araştırmada yetenek yönetimine ilişkin değerlendirmeler yapılmıştır. $\mathrm{Bu}$ değerlendirmeler sonunda, yeteneklerin ayırt edici özellikleri olduğunu, yetenekli kişiler kavramını "doğuştan gelen kabiliyetleri olan, gelişime, yeni şeyler öğrenmeye ve değişime açık, başkalarının görmediğini görebilen, ekip arkadaşları için rol model olan, departman içi ve departmanlar arası ilişkilerini yönetebilen, şirket değerleriyle uyum sağlayabilen istekli kişiler" tanımladıkları belirlenmiştir. Odak grup çalışmasında katılımcıların yarısı kendi kurumlarında yetenek yönetimi programı olduğunu 
bahsedilmiştir. Yetenek yönetimi programlarının uygulama amaçlarında en çok yedekleme yapmak, çalışan motivasyonunu yükseltmek ve elde tutmayı kolaylaştırmaktan belirtilmiştir. Odak grup çalışmasına katılanların yetenek yönetimi programlarının şeffaf olması gerektiği vurgulanmıştır. Gelişim fursatları açısından yetenekli ve yüksek potansiyelli olanlar için kişisel gelişim planları hazırlanması, koçluk imkânı ve mentorluk sisteminin sağlanması katılımcıların sundukları ve düşündükleri önemli firsatlar arasında yer almaktadır. Diğer bir açıdan bakıldığında, yetenek yönetimi programının uygulanmasındaki en önemli zorluğun tepe yönetimin bakış açısı, süreci desteklememesi üzerinde durulmaktadır.

Odak grup çalışmasına gelen yöneticilere ve uzmanlara dört soruluk ufak bir anket uygulanmıştır. Bu anket sonucunda; yetenek yönetiminin uygulama amaçları önem sırasına göre sıralandığında en önemli amaç olarak yeteneklerin şirket içinde elde tutulması gösterilmiştir. Katılımcılar ilk olarak yetenek olarak gördükleri ve ileride beklentileri olan çalışanlarını işletmede tutmayı önemli bir amaç olarak görmüşlerdir. Yetenek yönetimine alınacak kişilerin özelliklerinin değerlendiricileri ile ilgili ifadeler önem sırasına göre listelendirilmiştir. Listelendirilen ifadelere bakıldığında en önemli ifadenin şirket içerisinde oluşturulan değerlendirme merkezlerinde belirlenmesi yönünde ifade olduğu belirlenmiştir. Yetenek yönetimi programı ile elde edilmek istenen sonuçların önem sırası belirlenmiştir. Stratejiye en fazla katkıda buluna kritik roller için projelerin devamlılığını sağlama ifadesi en önemli ifade olarak belirlenmiştir. Katılımcılara son soru olarak yetenek yönetimi programının uygulanmasındaki zorluklar sorulmuştur. Verilen cevaplarda en önemli zorluğun şirket genel politikaları ve stratejileri ile yaşanan uyumsuzluk olduğu belirlenmiştir.

Sonuç olarak, araştırma sonuçları yetenek yönetimi programlarının işletmelerin yarısında olduğu, yeteneklerin ayırt edici özellikleri olduğu, programın en çok yedekleme için kullanıldığı ve motive edici etkisi olduğu belirlenmiştir. Yetenek yönetimi programlarının şeffaf olması gerektiği büyük bir oranda kabul edilmiştir. Yetenek programına girenlerin geliştirilmesi konusu önem verilmesi gereken bir konu olarak belirlenmiştir. Yetenek yönetimi programının en zor yönünün tepe yönetimin bakış açısı olduğu belirlenmiştir. En önemli amaç olarak da yeteneklerin elde tutulması kavramı olduğu ve bunlar için çeşitli yöntemler uygulanması gerektiği belirtilmiştir.

$\mathrm{Bu}$ çalışma yetenek yönetimine yönelik İzmir ve Manisa ilinde sınırlı sayıda yönetici ve uzman ile gerçekleştirilmiştir. Bu yönüyle araştırmanın sonuçlarına dayanarak tüm sektör için bir genelleme yapmak doğru olmaz. Bundan sonra yapılacak çalışmalar için Türkiye genelinde daha geniş kapsamlı bir uygulamanın yapılması, sınırlı tutulmayarak, tüm Türkiye'de daha dengeli sayıda örneklemle gerçekleştirilmesi hususlarının ele alınması tavsiye edilmektedir. 


\section{KAYNAKÇA}

ASTHON, C. ve MORTON, L. (2005). "Managing Talent for Competitive Advantage", Strategic HR Review, 4(5): 28-31.

BOUNDREAU, J.W. ve RAMSTAD, P.M. (2005). "Talentship and the new paradigm for human resource management: From Professional practice to strategic talent decision science", Human Resource Planning, 28(2): 17-26.

BOUDREAU, J.W. ve RAMSTAD, P.M. (2007). Beyond HR: The new science of human capital. Boston: Harvard Business School Press.

BÜYÜKÖZTÜRK, Ş. vd. (2013). Bilimsel Araştırma Yöntemleri, Pegem Akademi, Geliştirilmiş 14. Baskı, Ankara.

BYHAM, W.C., SMITH, A.B. ve PAESE, M. J. (2002). Grow your own leaders: How to identify, develop and retain leadership talent. Upper Saddle River, NJ: FinancialTimes Prentice Hall.

CARDEN, S.D. , Mendonca, L.T. ve Shavers, T. (2005). "What global executives think about growth and risk", The McKinsey Quarterly, Number 2: 16-25.

CHARAN, R. ve BOSSIDY, L. (2002). Execution: The discipline of getting things done. New York: Crown.

CHARAN, R., BARTON, D. ve CAREY, D. (2015). "People Before Strategy: A New Role for the CHRO", July-August: 63-71.

COLLINGS, D.G. ve MELLAHI, K. (2009). "Strategic Talent Management: A review and research agenda", Human Resource Management Review, 19: 304-313.

COSH, J.M., KHURANA, R. ve REEVES, L. (2005). "Growing Talent as if Your Business Depended on it", Harvard Business Review, October: 63-70.

ÇOKLUK, Ö., YILMAZ, K. ve OĞUZ, E. (2011). "Nitel Bir Görüşme Yöntemi: Odak Grup Görüşmesi”, Kurumsal Eğitimbilim Dergisi, 4 (1): 95-107.

DUTTAGUPTA, R. (2005). Identifying and managing your assets: Talent management. London,UK: PricewaterhouseCoopers.

FRANK, F.D., FINEGAN, R.P ve TAYLOR, C.R. (2005). “ The Race for Talent: Retaining and Engaging Workers in the 21 st Century", Human Resource Planning: 12-25.

GOCHMAN, I. ve STORFER, P. (2014). "Talent for Tomorrows: Four Secrets for HR Agility in an Uncertain World", People and Strategy, Vol.37, Issue 2: 25-28.

GUBMAN, E.L. ve GREEN, S. (2000). The four stages of talent management. San Francisco: Executive Networks.

GUTHRIDGE, M., KOMM, A.B. ve LAWSON, E. (2006). "The People in talent management", The McKinsey Quarterly, Number 2: 6-8.

HAID, M. (2012)." Why You Need a Talent Strategy", Talent Management Magazines, April: 30-33.

HAMBRICK, D.C. ve MASON, P.A. (1984). "Upper echolons: The organization as a reflection of its top managers", Academy of Management Review, 9: 193-206.

HAY GROUP (2008). Potential for What? 
HENEMAN, H.G. ve HANDEL, J. (2000). "Companies battle talent drain”, Workspan, Sept. :16-72.

HUSELID, M.A., JACKSON, S.E. ve SCHULER, R.S. (1997). "Technical and Strategic Human Resource management Effectiveness Determinates of Firm Performance", Academy of Management Journal, 40: 171-188.

HUSELID, M.A. ve BECKER, B.E. (2011). "Bridging Micro and Macro Domains: Workforce Differentiation and Strategic Human Resource Management", Journal of Management, June: 421-428.

JERUSALIM, R.S. ve HAUSDORF, P.A. (2007). "Managers' Justice perceptions of high potential identification practices", The Journal of Management Development, 26(10): 933-950.

KETS deVRIES, M.F.R.(2012). "Star Performers: Paradoxes Wrapped up in Enigmas", Organizational Dynamics, 41:173-182.

KPMG (2013). Time for a more holistic approach to talent risk. November. Publication number 130736.

KUŞ SAILLARD, E. 2009). Nicel-Nitel Araştırma Teknikleri, Anı Yayıncılık, 3. Baskı, Ankara.

McCAULEY,C. Ve WAKEFIELD, M.C. (2006). "Talent management in the 21st. Century: Help Your Company Find, Develop and Keep its Strongest Workers", The Journal of Quality and Participation, Winter:4-7.

MERCER LLC (2014). Mercer Survey Panel: North American Critical Talent Practice Survey.

MICHAELS, E., HANDFIELD-JONES, H. ve AXELROD, B. (2001). The War for Talent. Boston: Harvard Business School Press.

MILLER, C.C., BURKE, L.M. ve GLICK, W.H. (1998). "Cognitive diversity among upperechelon executives: implications for strategic decision processes", Strategic Management Journal, 19: 39-58.

MITCHELL, T.R., HOLTOM, B.C. ve LEE, T.W. (2001). "How to keep your best employees: Developing an effective retention policy", Academy of Management Executive, 15: 96-108.

LAWLER III, E.E. (2008). Talent: Making People Your Competitive Advantage. San Francisco: Jossey-Bass.

LEVENSON, A. (2014). "Organization design and talent strategies for emerging markets", Organizational Dynamics, 43: 205-213.

LISICAN E. (2013). "Get Talent Fit in 2013”, Talent Management Magazine January: 2427.

LOMBARDO, M.M. ve EICHINGER, R.W. (2000). "High Potentials as High Learners", Human Resource Management, Winter, Vol.39, No.4: 321-329.

OLDHAM, M. (2013). “Are You Doing Enough to Retain High Potentials?”, Talent Management Magazine, December:24-27. 
PASCAL, C. (2004). Foreword. In A.Schweyer (Ed.), Talent Management Systems: Best Practices in Technology Solutions for Recruitment, Retention and Workforce Planning. San Francisco, CA: John Wiley and Sons.

PwC (2012). "Delivering better business results through talent".

READY, D.A. ve CONGER, J.A. (2007).’Talent Factory”, Harvard Business Review, June: 69-72.

READY, D.A., CONGER, J.A. ve HILL, L.A. (2010). “Are You a High Potential?”, June: 78-84.

SCHULER, R.S. (1989). "Strategic Human Resource management and industrial relations", Human Relations, 42: 157-184.

SCHULERr, R.S. (2015). "The 5-C framework for managing talent", Organizational Dynamics, 44: 47-56.

SCULlin, H., COLLINGS, D.G. ve CALIGIURI, P. (2010). "Gobal talent management", Journal of World Business, 45: 105-108.

SHRM Foundation (2008). Retaining Talent. SHRM Foundations Effective Practice Guidelines Series, Alexandria, VA.

SHRM Globalforce (2015). SHRM Survey Findings: Employee Recognition Programs-2015.

SILZER, R. ve CHURCH, A.H. (2010). "Identifying and Assessing High-Potential Talent: Current Organizational Practices", R.Silzer ve B.E.Dowell (Eds.), Strategy-Driven Talent Management. San Francisco, CA: John Wiley and Sons.

SLOAN, E.B., HAZUCHA, J.F. ve VAN KATWYK,P.T. (2003). Strategic Management of Global Leadership Talent. In W.H.Mobley ve P.W.Dorfman (Eds.), Advances in global leadership, Vol.3 (s.235-274). New York, NJ: JAI.

STELL, R.P., GRIFFETH, R.W. ve HOM, P.W. (2002). "Practical retention policy fort he practical manager", Academy of Management Executive, 16: 149-161.

STEWART, T,A. (1997). Intellectual Capital: The new wealth of organizations. New York: Doubleday.

TOWERSWATSON (2014). 2014 Global Workforce Study-At a Glance.

WRIGHT, P.M. ve McMAHAN, G.C. (1992). "Theoretical perspectives for strategic human resource management”, Journal of Management, 18: 295-320.

ZUBOFF, S. (1988). In the age of the smart machine: The future of work and power. New York: Basic Books. 